This is a self-archived version of an original article. This version may differ from the original in pagination and typographic details.

Author(s): Valentini, Chiara

Title: Mapping public relations theory : Concluding reflections and future directions

Year: 2021

Version: Published version

Copyright: (c) 2021 Mouton De Gruyter

Rights: In Copyright

Rights url: http://rightsstatements.org/page/lnC/1.0/?language=en

Please cite the original version:

Valentini, C. (2021). Mapping public relations theory : Concluding reflections and future directions . In C. Valentini (Ed.), Public Relations (pp. 615-628). Mouton De Gruyter. Handbooks of Communication Science, 27. https://doi.org/10.1515/9783110554250-032 


\title{
32 Mapping public relations theory: Concluding reflections and future directions
}

\begin{abstract}
This chapter reviews and discusses the status of public relations theory. It does so by offering the editor's own reading and interpretation of public relations theory as discussed in this handbook. Specifically, a typology for classifying public relations theories is presented, and then used to conduct a meta-level theoretical analysis of the theories presented in Part III. The typology is based on three major theoretical objectives (normative, descriptive, and instrumental), and three perspectives (managerial, public, and conceptual). Concluding reflections on the status of public relations theory and suggestions for the future direction of research are offered.
\end{abstract}

Keywords: public relations theory; heuristic typology; theoretical perspectives; theoretical objectives; theorizing

"He who loves practice without theory is like the sailor who boards ship without a rudder and compass and never knows where he may cast.” Leonardo da Vinci

\section{Introduction}

Over 500 years ago, the Italian artist and scientist Leonardo da Vinci already recognized that practice without theory is useless. Not only has public relations as a professionalized practice grown in relevance in today's societies, but its body of knowledge has also expanded, and it is gaining momentum through further theorizing. But why bother to reflect on public relations theory? Perhaps it is because "executing effective public relations starts with knowing and understanding the public relations theory that helps define the practice" (Toth and Dozier 2018: 71). But a theory is much more than that; as Brunner (2019) noted, it helps people to see new and valuable things (Littlejohn 1999), and helps in predicting or explaining future outcomes (Griffin et al. 2015). Although public relations has earned a role - albeit sometimes negative - in organizational and societal matters, it has not yet attained an adequate status among the broad scientific community; I believe it can and should realize such a place. There is already evidence that public relations scholars are increasingly engaging with socially important objectives, questions, and debates that intersect different disciplinary traditions, principal specialties, methodologies, and schools of thought (for examples see Adi 2019; Brunner 2016; Johnston 2016; Johnston and Taylor 2018). These actions illustrate that public relations can also contribute to the understanding 
of, and offer a contribution to, solving diverse problems. As the contributors of this handbook have shown, public relations is a multi-faced profession handling many different communication and non-communication activities. It is a profession with own identity, but is often not clearly understood or accepted by others. It is trying to bring value to how organizations of any kind, including publics as well as stakeholders, engage in different types of relations and conversations. In order to pay tribute to the fact that public relations has evolved from a managerial practice into a more comprehensive research field, and now comprises a collection of theories, models, and thinking - what we can refer to as public relations theory - we must first reflect upon what kind of theories we have.

This concluding chapter thus intends to offer the editor's own reading and interpretation of public relations theory as discussed in this handbook. This handbook presents a variety of theories, theoretical approaches, and paradigms that contrast and sometimes collide one with another. This may give the impression that public relations theory is chaotic. Yet, it could also be interpreted as a healthy academic effort by a field attempting to challenge its own assumptions and ideas through multiple views and philosophical perspectives.

Scholars tend to be familiar with the specific theories they use in their own research. Yet, rarely do they think about the purpose, definition, or meaning of theory itself, especially in a field like public relations, that disagrees on its own theoretical foundations and the research questions it should address. Recognizing public relations theory as an essentially contested field, subject to multiple competing interpretations, this chapter presents a meta-level theoretical analysis of the theories considered classical public relations (Part III). This exercise is a parsimonious attempt to wrap up the contributions of this volume, and thus bears the limits of the discussed public relations theories.

To embark on this endeavor, it is important to start by summarizing the most important challenges to contemporary public relations theory, which number at least three. First, although multiple paradigms and perspectives have been explored, especially in recent years, public relations theory is still lacking a widely accepted normative foundation (Brunner 2019; Botan and Hazleton 1989). For many years, excellence theory has dominated public relations research, but rhetorical theory, dialogic theory, contingency theory, and community-building theory have also taken their share of attention as first-order public relations theories. Interpretivist approaches have also emerged as new forces in scholarly theorizing efforts, but no specific public relations theory has yet emerged from that standpoint. Second, public relations theory is still weak in terms of descriptive and empirical analyses of the diverse forms of public/ stakeholder-organization interactions. Most research has crystalized around the positivist idea of an organization managing relationships with specific active publics at a single point in time; there has not been much research on intra- and inter-organizational relations, nor much about stakeholder relations or organizationS-stakeholderS relationships (Heath 2013; Sommerfeldt and Kent 2015, Valentini et al. 2012). Third, 
if the discipline needs to advance, we must then consider theorizing about theories and concepts themselves as an important scientific outcome. Although some developments on this subject have appeared (Coombs and Holliday 2019; Ferguson 2018; Grunig J. 2006; Heath 2006; Ledingham 2003), they are too few and limited in scope.

This concluding chapter addresses the third challenge by mapping these developments as discussed in this handbook, and putting them into a "typology of theories". Summarizing and drawing parallels is always a difficult exercise, and often falls short of adequately representing the types of sophisticated thinking that underpins each of the different theoretical approaches presented in this volume. Yet, such an exercise is badly needed if the uncertainty regarding the actual scope of public relations theories is to be reduced. While I tried to embark on this process of mapping and classifying with a detached, objective vision, my knowledge of the field and my academic background have undoubtedly influenced the way I see and understand these theories. That is to say, I do not expect that all of the contributors to this volume will agree with my classification of their work into the categories described in the heuristic typology I propose.

\section{Mapping public relations theory: a typology}

The proposed typology for mapping the theoretical body of knowledge in public relations takes its point of departure from a similar analytical approach used for classifying major public relations theories addressing globalization (cf. Valentini 2019), and is inspired by early stakeholder management literature (Donaldson and Preston 1995; Friedman and Miles 2006; Steurer 2006). The proposed typology is a heuristic attempt to organize theories by their theoretical objectives - which can be normative, descriptive, or instrumental - and by their perspectives - which, in this analysis, I chose to classify as managerial, public, or conceptual (see Table 1). It has been argued that combining objectives and perspectives in analyzing a field's theories can offer a more systematic and in-depth approach to learning about the actual scope of a field's theoretical development (Steurer 2006). The first dimension, the theoretical objective, responds to the ontological question of what kind of knowledge a theory offers. Normative theories are essentially theories about how the world should be or work. They display clear similarities with the deductive method, in that their intention is to apply general principles (often based on ethical considerations) to specific cases. Typically, the two types of normative elements are referred to as the normativity of outcomes and the normativity of justification, with the former considered to have a superior moral foundation (Friedman and Miles 2006). Descriptive theories, also known as positive theories, are theories about how the world actually is or works (Grunig J. and Grunig L. 1992). These theories tend to show similarities to the inductive approach, since, differently than normative theories, they try to derive general principles and conclu- 
sions by examining individual cases. Instrumental theories, on the other hand, are theories about how the world would be if something happens or is done. Instrumental theories, also known as prescriptive theories, essentially examine ceteris paribus connections, and offer guidelines that describe what to do in order to achieve specific outcomes (Donaldson and Preston 1995). Instrumental theories thus concern both the normative/deductive and the descriptive/inductive approach, but their characteristic element is a focus on causalities through linking means and ends (Steurer 2006).

The second dimension of the typology is the theoretical perspective. This refers to the thematic width of a theory, and essentially it examines the specific problems underlined in the theoretical premises. In this analysis of public relations theory, I propose to use managerial, public, and conceptual perspectives. As has been noted on several occasions (e.g. Ihlen and Verhoeven 2009; Edwards 2018; Valentini and Edwards 2019), the field has expanded significantly from a narrow view of public relations as the management of symbols and meanings for corporations and powerful entities to include a broader view of public relations as a cultural, social, and public practice dealing with the negotiation of both meaning and behavior. Reviewing the key conceptual foundations in public relations literature, Coombs and Holladay (2019) found that the three main concepts are organizations, publics, and relationships. Ihlen and Verhoeven (2009) identified a number of other relevant concepts in addition to relationships, such as trust, legitimacy, understanding, and reflections. In several ways, it is thus possible to see a pattern among early scholarly discussions on the core public relations concepts and perspectives, resulting in the conclusion that it is possible to classify the diverse body of public relations theories into managerial, public, and conceptual perspectives. Similar perspectives have also been employed in management literature interested in stakeholder theory (Donaldson and Preston 1995; Friedman and Miles 2006; Steurer 2006), which I would argue shares a high degree of similarity in research questions - at least those concerning stakeholders - with public relations. My choice of a managerial perspective rather than an organizational one relies on the fact that the former term includes an organizational perspective, but is not limited to it; it is thus best suited to capture the socio-cultural turn of public relations, which would fit too tightly under the umbrella of "organization". In the proposed typology, a public perspective has a broad view, and captures a range of different actors such as stakeholders, stake-seekers and stake-watchers (Fassin 2009), influencers, claimants, collaborators and recipients (Miles 2017), non-publics, and the general public (Hallahan 2000). Finally, I chose not to focus on a specific concept, and thus used a conceptual perspective in order to open up the discussion to a wider set of concepts, not limited to relationship, trust, legitimacy, etc.

Ultimately, the managerial perspective focuses on how public relations deals with publics, stakeholders, and society, while the public perspective analyzes how publics, stakeholders, and society try to influence organizations and any kind of organized entity for which public relations operates, and the conceptual perspective explores how particular concepts such as trust, power, legitimacy, mutuality, symmetry, or 
dialogue relate to public relations practice or theory. The three perspectives proposed here are an attempt to complement and expand the scope of analysis of other reviews of public relations theories, by providing not just managerial reflections but also public and conceptual reflections on the object of public relations theory in a more systematic and parsimonious manner. In the next section, I apply this typology to the theories presented in Part III of this handbook.

Table 1: A typology of classification for public relations theory (modified from Steurer 2006: 62)

\begin{tabular}{|c|c|c|c|c|c|}
\hline & & & Public relat & ions theory perspectives & \\
\hline & 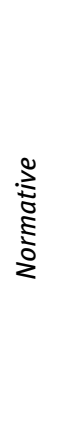 & $\begin{array}{l}\text { Main } \\
\text { question }\end{array}$ & $\begin{array}{l}\text { Managerial } \\
\text { Interprets the function } \\
\text { of public relations } \\
\text { regarding publics and } \\
\text { wider society } \\
\text { Why and how should } \\
\text { public relations deal } \\
\text { with publics and soci- } \\
\text { etal matters? }\end{array}$ & $\begin{array}{l}\text { What makes publics } \\
\text { legitimate, and how } \\
\text { should they try to } \\
\text { accomplish their inter- } \\
\text { ests? }\end{array}$ & $\begin{array}{l}\text { Conceptual } \\
\text { Interprets the norma- } \\
\text { tive characteristic of } \\
\text { concept } X \text { and its signif- } \\
\text { icance for public rela- } \\
\text { tions practice/theory } \\
\text { What issues of concept } \\
X \text { should public rela- } \\
\text { tions and publics take } \\
\text { into account? }\end{array}$ \\
\hline 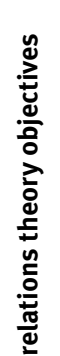 & 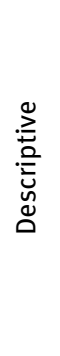 & $\begin{array}{l}\text { Main } \\
\text { question }\end{array}$ & $\begin{array}{l}\text { Describes public rela- } \\
\text { tions characteristics, } \\
\text { practices, and behav- } \\
\text { iors regarding publics } \\
\text { and society } \\
\text { How does public rela- } \\
\text { tions actually deal with } \\
\text { publics and societal } \\
\text { matters? }\end{array}$ & $\begin{array}{l}\text { Describes public char- } \\
\text { acteristics and behav- } \\
\text { iors regarding issues } \\
\text { and organizations } \\
\text { What do publics expect } \\
\text { or claim, and how do } \\
\text { they actually try to } \\
\text { achieve their claims? }\end{array}$ & $\begin{array}{l}\text { Describes how particu- } \\
\text { lar issues of concept } \\
X \text { play a role in public } \\
\text { relations practice/ } \\
\text { theory } \\
\text { Which issues of con- } \\
\text { cept X do public rela- } \\
\text { tions and/or publics } \\
\text { take into account? }\end{array}$ \\
\hline 总 & 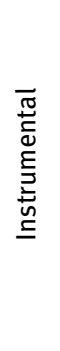 & $\begin{array}{l}\text { Main } \\
\text { question }\end{array}$ & $\begin{array}{l}\text { Analyses the connec- } \\
\text { tion between public } \\
\text { relations practice and } \\
\text { public relations goals } \\
\text { How can public rela- } \\
\text { tions practice contrib- } \\
\text { ute to an organization's } \\
\text { performance? }\end{array}$ & $\begin{array}{l}\text { Analyses the connec- } \\
\text { tion between a public's } \\
\text { strategy and its ability } \\
\text { to meet the public's } \\
\text { claims } \\
\text { How can publics best } \\
\text { accomplish their } \\
\text { claims? }\end{array}$ & $\begin{array}{l}\text { Analyses the connec- } \\
\text { tion between public } \\
\text { relations practice/the- } \\
\text { ory and the realization } \\
\text { of concept } X \\
\text { To what extent can } \\
\text { concept } X \text { be achieved } \\
\text { through public rela- } \\
\text { tions practice? }\end{array}$ \\
\hline & $\begin{array}{l}\overline{\bar{\pi}} \\
\frac{0}{0} \\
0\end{array}$ & $\begin{array}{l}\text { Main } \\
\text { question }\end{array}$ & $\begin{array}{l}\text { Public relations in/for } \\
\text { organizations/causes } \\
\text { How does public rela- } \\
\text { tions relate to publics } \\
\text { or an issue? }\end{array}$ & $\begin{array}{l}\text { Publics'/stakeholders' } \\
\text { claims and public rela- } \\
\text { tions practice } \\
\text { How do publics address } \\
\text { organizations? }\end{array}$ & $\begin{array}{l}\text { Concept } \mathrm{X} \text { and public } \\
\text { relations practice/ } \\
\text { theory } \\
\text { How does concept } \mathrm{X} \\
\text { relate to public rela- } \\
\text { tions practice/theory? }\end{array}$ \\
\hline
\end{tabular}




\section{The status of public relations theory}

In part III of this volume, twelve theories, two of which are further elaborations of old theories, were presented and discussed in ten chapters. By focusing on the main features as described by the authors, it is possible to extrapolate their theoretical objectives and perspectives. As Table 2 shows, most of these public relations theories are normative or descriptive, and predominantly take a managerial perspective.

Table 2: Mapping classical public relations theories by theoretical objectives and perspectives

\begin{tabular}{lll}
\hline Theories & Theoretical objectives & Theoretical perspectives \\
\hline Excellence theory & Normative & Managerial \\
Relationship management theory & Normative & Managerial \\
Community-building theory & Normative & Conceptual \\
Organic theory of public relations & Normative & Conceptual \\
Dialogic theory of public relations & Normative & Conceptual \\
Rhetorical theory of public relations & Normative, descriptive & Managerial, public \\
Four models of public relations & Descriptive & Managerial \\
Personal influence model of public relations & Descriptive & Managerial \\
Contingency theory of strategic conflict & Descriptive & Managerial, public \\
management & & \\
Global public relations theory & Descriptive & Conceptual \\
Situational theory of publics & Instrumental & Public \\
Situational theory of problem-solving & Instrumental & Public \\
\hline
\end{tabular}

While not a surprise, a managerial perspective emphasizes specific professional or organizational characteristics and managerial behaviors regarding publics and stakeholders (descriptive), or identifies connections or the lack of them to the achievement of traditional public relations goals (instrumental), or interprets the function of public relations, including the identification of moral or philosophical guidelines (normative). Given the historical legacy of public relations as a form of publicity and even propaganda, many scholars may have attempted to "redeem" its identity by elaborating on its practice and function through ethical and moral lenses. This is perhaps a plausible explanation for the great amount of attention given to managerial and normative theories.

J. Grunig and L. Grunig (1992) do not shy away from saying that Excellence theory should be considered the grand theory of public relations, as its objective is to guide the practice of public relations professionals toward what they consider "excellence", thus underlining both its normative and managerial grounds. On the same line, Relationship management theory can be considered a normative theory with a managerial perspective, as it takes its own foundation from Systems theory, Stakeholder theory, Social responsibility theory, and Crisis management theory, and interprets the function of public relations in light of these theories and the practice of managing rela- 
tionships with publics and stakeholders. While relationship management has been recognized as one of - if not the - central paradigms of public relations (cf. Ferguson 2018), the theory underpinned by Ledingham in chapter 21 offers a moral, ethical ground for practicing public relations based on the management of public concerns.

Community-building theory and the Organic theory of public relations are also normative theories, in that they try to guide the practice of public relations from a different viewpoint, which is through the lenses of two concepts, and thus their perspective is considered conceptual. A normative theory with a conceptual perspective discusses public relations problems from a particular concept's vantage point and searches for a moral or theoretical ground for public relations, or explores how public relations relates to a particular concept (Steurer 2006). While Community-building theory and the Organic theory of public relations are grounded on the concepts of community and organic, they consider the public relations, organizational, and societal interests from the perspective of these concepts, and from the theory of society.

The Dialogic theory of public relations is another theory of this kind. It is a normative theory, since it offers moral grounds to practice public relations in honest and ethical ways while trying to create effective organization-public communications (Kent 2003). It also discusses the moral foundations of ethical communication through the lenses of dialogue and dialogic communication, and thus searches for a moral ground for public relations through the concept of dialogue. Hence, it is classified as a conceptual perspective.

Another example of a normative theory is the Rhetorical theory of public relations, the main purpose of which is to explain how humans can achieve a fully functioning society. Yet, the same theory also offers many descriptive elements, based on observations and rhetorical literature, on how humans communicate and try to influence each other. This theory contains some elements of a real-life description; thus, its theoretical objective is hybrid. Furthermore, this theory addresses both managerial and public perspectives. While Heath, Waymer, and Ihlen claim (see Chapter 18 in this book) that the Rhetorical theory of public relations is essentially organization-centric, thus emphasizing the managerial perspective, they later acknowledge that any social actor can use rhetoric to influence the communication dynamic through the use of discourse enactments. Thus, this theory is constructed to respond to both managerial (public relations, organizations) and public (any other social actor) perspectives.

Moving on to descriptive theories, earlier J. Grunig and L. Grunig (1992) argued that the Four models of public relations represents a good example of a descriptive public relations theory, since its foundations are confirmed by diverse empirical studies showing that public relations is performed according these models. In the same line, the Personal influence model of public relations, sometimes referred as the fifth model of public relations, can be considered a descriptive theory for similar reasons. Both the four models and the personal influence model show a managerial perspective, in that they describe how the management of public relations is actually done. Another descriptive theory is the Global public relations theory by Verčič 
and Sriramesh, which is essentially a spin-off of the Excellence Project. This theory briefly tries to explain how societal, cultural, and system elements - such as media, activism, and civil society - affect the practice of public relations. Therefore, it can be considered a descriptive theory with a conceptual perspective, because it describes how particular elements characterizing the concept "global" (media, culture, politics, activism, etc.) play a role in public relations practice.

An example of a special descriptive theory is the Contingency theory of strategic conflict management. It is descriptive because it explains how organizations or publics can influence each other through the communication of different stances. The theory describes how such stances change along a continuum, depending on the situation and the communication recipient. Yet, the theory also contains some core normative reflections, in that it recommends a rethinking of how public relations can take place. Nonetheless, this theory has been classified as descriptive in this typology, as its core assumptions were developed through many empirical studies, and its main features were thus inductively derived. Concerning the theoretical perspective, this theory responds to both managerial and public concerns, albeit that the theory was primarily developed to address managerial ones. The explicative power of this theory is much broader than that of public relations and organizations. Focusing on describing stance movements, it can explain how any social actor or organized entity could use such stances to influence the other. As a result, contingency theory is considered a descriptive, yet managerial- and public-oriented, theory.

Only two classical theories have an instrumental perspective. The Situational theory of public and the Situational theory of problem solving represent good illustrations of two instrumental theories, since both examine the communicative behaviors of publics to forecast possible actions, and thus link the "means and ends". Both theories, in fact, analyse the connection between a public's strategy/behavior and its ability to influence an organization. Because these theories take a public's viewpoint, they can be considered to have a public perspective, as their primary role is understanding how publics and stakeholders can affect an organization.

\section{Concluding reflections and future directions}

Three major conclusions merit being mentioned here. First, public relations theory consists of a discrete amount of theories dealing with normative, descriptive, and instrumental objectives, albeit normative and descriptive scopes are predominant. Perhaps it is now time to move toward developing instrumental theories. As Wehmeier (2009) noted, if public relations theory ought to address professional problems, we must generate theories that can help professionals to handle them. Thus, we must focus more on theories of the middle range, particularly those of an instrumental nature. For example, specialized areas of public relations, such as crisis communi- 
cation, have developed a set of instrumental theories that can serve this purpose. We must look behind the crises and imminent issues and also address broader societal and public concerns by expanding our toolkit of instrumental theories; for example, to address compelling questions on societal and geo-cultural matters such as climate change, terrorism, health outbreaks, immigration, conflict, use of natural resources, etc. What kind of a role does public relations have as an organizing function in these bigger problems? Does it hinder or facilitate them? How? Instrumental theories could then analyse the connection between public relations practice/theory and the specific issue or question at stake, and offer guidelines that describe what to expect if certain actions are taken.

Second, most public relations theories have a managerial outlook. This is not surprising, given that most of theories in this volume are either about defining the identity and function of public relations, or assisting in its practice. Yet, there are also some conceptual perspectives in public relations theory, and, if we consider part IV of this volume, we could argue that many of the recent theorizing efforts are essentially conceptual: that is, they try to borrow and adapt a concept from a discipline and apply it to public relations problems. What is actually needed is a public perspective on public relations theory. For example, what kind of public relations theory can we develop out of the recent work on social advocacy, activism, and community? What can we theorize about public behaviors and influencing strategies? These are examples of new areas that have only been briefly explored. Empirical studies - for example, on employee whistleblowing (Greenwood 2015), voicing (Tam et al. 2018), public negative engagement (Lievonen et al. 2018) and other topics - are increasing in number, but there is a fundamental gap in theory development here. It is time to move from empirical case studies to theory.

Third, most classical public relations theories are western-centric; that is, they are highly influenced by western thinking and theorizing practices. While it could be argued that normative theories should essentially be able to normatively explain public relations practice across cultures, empirical case studies show often they fall short of completely explaning the phenonmenon. Yet, alternative, non-western theories from public relations are essentially non-existent. There is a substantial gap in theorizing from the non-western world in this discipline. Theories addressing public relations from a non-western perspective would be of great value across the full range of normative, descriptive, instrumental objectives and managerial, public, and conceptual perspectives.

To add to this, I would argue that an understanding of public relations as an organizing function, as I described in the Introduction to this handbook, rather than an organizational function, may turn to be more useful in helping the scientific community to theorize beyond the western, capitalist view of public relations. The idea of organizing can also dissolve the dichotomy between theory and practice, as the identity of public relations is defined by what it does and what it produces, and this is not fixed or structured, but flexible (Langenberg and Wesseling 2016). Many of the the- 
ories presented in Part III appear to have in common an emphasis on agency, rather than on the loci of function. They essentially expose what public relations can do through communication, and thus somehow illustrate the back-and-forth movement and translation between the actions of public relations and their interpretation, which is essentially the idea of organizing (Weick 1979). The rethinking of public relations as an organizing function also calls for more reflection on the actual impact, and added value, of this profession on and for organizations, publics, and societies. This could be a fruitful approach to develop a consistent narrative across schools of thought, and a grand theory of public relations.

Public relations scholars may not agree on the best theory, nor even on what can be considered a theory of or for public relations, yet this overview of public relations theory through a typology of classification hopes to shed some light on which type of theories are still needed to better understand certain aspects of public relations (Brunner 2018; Grunig J. 1992). A brief disclaimer is needed here. As with most typologies, this classification typology, based on theoretical objectives and perspectives, has to be understood as a simplified review, derived from a selection of the important tenets of each theory. Obviously, reality is not always as orderly as theory would hope. Many public relations theories often follow more than one objective, and identifying which of the three perspectives a theory uses can be difficult. Likewise, the typology falls short in showing theoretical interactions, and these can be productive efforts in theorizing. Regarding other biases of the proposed typology as a classification instrument, it has been noted in management literature that several theories with an instrumental approach also have a normative core as well, and that several normative theories derive their managerial insights from empirical case studies, and thus through direct observations (Steurer 2006; Freeman 1999). There is no reason for not seeing similar challenges in classifying public relations theory, as much of what characterizes public relations also characterizes the management of stakeholder relations - albeit from a communication angle. Despite the limits of this systematic and, at times, simplistic approach to classifying public relations theory, I believe this typology and the exercise performed here can capture, in its very simplicity, the essence of what public relations theory is today, and show in what direction scholars should steer in the future.

In conclusion, I hope the reader will find it enlightening and useful to look at the different theoretical approaches, models, and concepts that are collected in this volume. Public relations as an organizing function takes place at multiple levels: organizational, societal, and even individual. Much of what public relations does, provokes, or responds to is communicatively embedded, which is why we should not forget the communication origin of public relations. A communication perspective emphasizes both the constitutive nature of communicating and the process of meaning creation (van Ruler 2018). Through this lens, communication becomes the means by which public relations professionals convey meanings and ideas toward publics and stakeholders, for instance via campaigns and messaging. Communication can also be 
a means of developing an understanding of different environments by monitoring, observing, and analyzing people's communicative behaviors (Valentini 2018), which organizations, clients, and communities may expect to be advised on. Communication can thus be not only a result, a campaign, a message, content, etc., but also an antecedent for understanding complexity and public and stakeholder interests. Furthermore, communication can be a process for creating meanings, structures, and practices, particularly because communication can be performative in constituting a reality, or simply institutionalizing practices and activities in organizations (Valentini 2018). I think this is important, and we should not forget it when trying to advance public relations notions, and trying to theorize about problems and issues that affect the profession.

As stated in the Introduction chapter, public relations is essentially a profession in the "business" of social influence. It has a specific focus and purpose, albeit that agreement on what this should be is still contested. Yet in my view, the beauty of this discipline is exactly the diversity of its methodological and theoretical premises, and its increasing curiosity about exploring and expanding its own boundaries. It is also important to note that, although the contributors to this volume have reviewed and discussed their topic thoroughly, there is more that could be gained from others who could not be included in this handbook. Some of these recent studies are inspiring, and should be taken into consideration, as they could lead to new theorizing in the near future.

\section{References}

Adi, Ana. 2019. Protest public relations. Communicating dissent and activism. New York: Routledge. Botan Carl H. \& Vincent Hazleton. 1989. Public Relations Theory, Vol. I. Hillsdale, NJ: Lawrence Erlbaum Associates.

Brunner, Brigitta R. 2016. The moral compass of public relations. New York: Routledge.

Brunner, Brigitta R. 2019. Public relations theory: Application and practice. Medford, MA: Wiley Blackwell.

Coombs, W. Timothy. 2010. Parameters for crisis communication. In Timothy W. Coombs \& Shelly J. Holladay (eds.), Handbook of Crisis Communication, 17-53. Malden, MA: Wiley-Blackwell.

Coombs, Timothy W. \& Sherry J. Holladay. 2019. The conceptual heritage of public relations: Using public memory to explore constraints and liberation. Journal of Communication Management 23(4). 375-392.

Donaldson Thomas and Lee E. Preston 1995. The stakeholder theory of corporation: Concepts, evidence, and implications. The Academy of Management Review 20(1). 65-91.

Edwards, Lee. 2018. Understanding public relation. Theory, culture and society. London: Sage. Fassin, Yves. 2008. The stakeholder model redefined. Journal of Business Ethics 84(1). 113-135.

Ferguson, Mary Ann. 2018. Building theory in public relations: Interorganizational relationships as a public relations paradigm. Journal of Public Relations Research 30(4). 164-178.

Freeman, Edward R. 1999. Divergent stakeholder theory. Academy of Management Review 24(2). 233-236. 
Friedman, Andrew L. \& Samantha Miles. 2006. Stakeholders: Theory and Practice. Oxford: Oxford University Press.

Greenwood, Cary A. 2015. Whistleblowing in the Fortune 1000: What practitioners told us about wrongdoing in corporations in a pilot study. Public Relations Review 41(4). 490-500.

Griffin, Em, Andrew Ledbetter \& Glenn Sparks. 2015. A first look at communication theory, $9^{\text {th }}$ edn. New York: McGraw Hill Education.

Grunig, James E. 1992. Excellence in public relations and communication management. Hillsdale, NJ: Lawrence Erlbaum Associates.

Grunig, James E. 2006. Furnishing the edifice: Ongoing research on public relations as a strategic management function. Journal of Public Relations Research 18(2). 151-176.

Grunig, James E. \& Larissa A. Grunig. 1992. Models of public relations and communications. In James E. Grunig (ed.), Excellence in public relations and communication management, 285-326. Hillsdale, NJ: Lawrence Erlbaum Associates.

Hallahan, Kirk. 2000. Inactive publics: The forgotten publics in public relations. Public Relations Review 26(4). 499-515.

Heath, Robert L. 2006. Onward into more fog: Thoughts on public relations research directions. Journal of Public Relations Research 18(2). 93-114.

Heath, Robert L. 2013. The journey to understand and champion OPR takes many roads, some not yet well traveled. Public Relations Review 39(5). 426-431.

Ihlen, Øyvind \& Piet Verhoeven. 2009. Conclusions on the domain, context, concepts, issues, and empirical venues of public relations. In Øyvind Ihlen, Magnus Fredriksson \& Betteke van Ruler (eds.), Public relations and social theory: Key figures and concepts, 322-340. New York: Routledge.

Johnston, Jane. 2016. Public relations and the public interest. New York: Routledge.

Johnston, Kim \& Maureen Taylor. 2018. The handbook of communication engagement. Medford, MA: Wiley Blackwell.

Kent, Michael. 2003. The relationship between web site design and organizational responsiveness to stakeholders. Public Relations Review 29. 63-77.

Langenberg, Suzan \& Hans Wesseling. 2016. Making sense of Weick's organising. A philosophical exploration. Philosophy of Management 15(3). 221-240.

Ledingham, John A. 2003. Explicating relationship management as a general theory of public relations. Journal of Public Relations Research 15(2). 181-198.

Lievonen, Matias, Vilma Luoma-aho \& Jana Bowden. 2018. Negative engagement. In Kim Johnston \& Maureen Taylor (eds.), The handbook of communication engagement, 531-548. Medford, MA: Wiley Blackwell.

Littlejohn, Stephen W. 1999. Theories of human communication. Belmont, CA: Wadsworth.

Miles, Samantha. 2017. Chapter 2: Stakeholder theory classification, definitions and essential contestability. In David M. Wasieleski \& James Weber (eds.), Stakeholder management, 21-48. Bingley, UK: Emerald Publishing.

Sommerfeldt, Erich J. \& Michael L. Kent. 2015. Civil society, networks, and relationship management: Beyond the organization-public dyad. International Journal of Strategic Communication 9(3). 235-252.

Steurer, Reinhard. 2006. Mapping stakeholder theory anew: From the 'stakeholder theory of the firm' to three perspectives on business-society relations. Business Strategy and the Environment 15. 55-69.

Tam, Lisa, Jarim Kim \& Jeong-Nam Kim. 2018. The origin of distant voicing: Examining relational dimensions in public diplomacy and their effects on megaphoning. Public Relations Review 44(3). 407-418. 
Toth, Elizabeth L. \& David M. Dozier. 2018. Theory: The ever-evolving foundation for why we do what we do. In Commission for Public Relations Education, Fast forward: Foundations + future state. Educators + practitioners, 71-77. New York: Commission for Public Relations Education.

Valentini, Chiara. 2018. Communicatively constituted stakeholders: Advancing a communication perspective in stakeholder relations. In Adam Lindgreen, Francois Maon, Joelle Vanhamme, Beatriz Palacios Florencio, Christine Strong \& Carolyn Vallaster (eds.), Engaging with Stakeholders: A Relational Perspective on Responsible Business, 65-79. New York: Routledge.

Valentini, Chiara. 2019. Globalization. In Brigitta R. Brunner (ed.), Public Relations Theory: Applications and Understanding, 125-140. Hoboken, NJ: Wiley.

Valentini, Chiara \& Lee Edwards. 2019. Theories in public relations: Reflections and future directions. Public Relations Inquiry 8(3). 195-200.

Valentini, Chiara, Dean Kruckeberg \& Kenneth Starck. 2012. Public relations and community: A persistent covenant. Public Relations Review 38(5). 873-879.

van Ruler, Betteke. 2018. Communication theory: An underrated pillar on which strategic communication rests. International Journal of Strategic Communication 12(4). 367-381.

Wehmeier, Stefan. 2009. Out of the fog into the future: Directions of public relations theory building, research, and practice. Canadian Journal of Communication 34. 265-282.

Weick, Karl E. 1979. The Social Psychology of Organizing, 2nd edn. New York: McGraw-Hill. 
